\title{
Denman Island disease (causative agent Mikrocytos mackini) in a new host, Kumamoto oysters Crassostrea sikamea
}

\author{
Ralph A. Elston ${ }^{1, *}$, James Moore ${ }^{2}$, Cathryn L. Abbott ${ }^{3}$ \\ ${ }^{1}$ AquaTechnics, 455 W. Bell Street, Sequim, Washington 98382, USA \\ ${ }^{2}$ California Department of Fish and Game, Bodega Marine Laboratory, PO Box 247, Bodega Bay, California 94923, USA \\ ${ }^{3}$ Fisheries and Oceans Canada, Pacific Biological Station, 3190 Hammond Bay Road, Nanaimo, British Columbia \\ V9T 6N7, Canada
}

\begin{abstract}
Mikrocytos mackini, causative agent of Denman Island disease in Pacific oysters Crassostrea gigas and other oyster species, was found in 2011 in a previously unreported host, the Kumamoto oyster C. sikamea, in Humboldt Bay, California, USA. The detection was also the first reported finding of $M$. mackini in California. Prevalence was estimated as high as approximately $27 \%$ from pooled samples analyzed by PCR. Higher prevalence appeared related to longer residence time in the bay and somewhat colder than typical winter seawater temperatures. No M. mackini was detected in Humboldt Bay juvenile Kumamoto oysters or Pacific oyster brood or seed stock in 2011 or 2012.
\end{abstract}

KEY WORDS: Mikrocytos mackini $\cdot$ Denman Island disease $\cdot$ Kumamoto oyster $\cdot$ Crassostrea sikamea

Resale or republication not permitted without written consent of the publisher

\section{INTRODUCTION}

Denman Island disease (DID) is an infectious disease causing morbidity and mortality of Pacific oysters Crassostrea gigas and was first described by Quayle $(1961,1982,1988)$ in the vicinity of Henry Bay of Denman Island, which lies on the eastern aspect of Vancouver Island, British Columbia, Canada. The causative agent is an amitochondriate protistan parasite of undetermined taxonomic affinity (Abbott et al. 2011, cf. Carnegie et al. 2003), commonly referred to as a 'microcell' based on its histological presentation. These microcells, which are 2 to $3 \mu \mathrm{m}$ in diameter, primarily infect vesicular connective tissue and were designated Mikrocytos mackini by Farley et al. (1988). Infections may be manifested by grossly visible raised yellow to green pustules on the body surface or within the adductor muscle and are known to be transmissible directly from oyster to oyster (Bower et al. 1997). Disease expression requires prolonged environmental seawater temperatures in the range of $10^{\circ} \mathrm{C}$ or lower, while higher temperatures $\left(>15^{\circ} \mathrm{C}\right)$ are not permissive for disease expression (Hervio et al. 1996, Bower et al. 1997). Mortality from the disease has been observed in British Columbia but not elsewhere. Prior to this study, the known geographic range of M. mackini included British Columbia, Canada, adjacent areas of Washington State, USA, and one site in Oregon, USA, on the Pacific Northwest coast (Farley et al. 1988, Bower et al. 2005). The only previously known wild host species of M. mackini are Pacific oysters Crassostrea gigas and the Olympia oyster Ostrea conchaphila, but laboratory experimentation has shown that Eastern oysters $C$. virginica and European flat oysters $O$. edulis are also susceptible (Bower et al. 1997).

Based on the Shellfish High Health Program of the Pacific Coast Shellfish Growers Association (PCSGA 2010), routine disease surveillance is conducted on brood and seed stock populations of participating 
shellfish farms, consisting of independent sampling conducted by US Department of Agriculture accredited veterinarians. As a result of such routine surveillance in 2011, Mikrocytos mackini infections were discovered in a previously unrecognized host species, Kumamoto oysters Crassostrea sikamea in Humboldt Bay, California, a location previously unknown to harbor the disease agent.

\section{MATERIALS AND METHODS}

\section{Sample collection}

Kumamoto and Pacific brood and seed stock oysters were initially sampled $(n=600)$ from the northern arm of Humboldt Bay, in February 2011 as part of annual routine brood stock disease surveillance (Table 1). Samples are collected by an independent veterinarian accredited by the US Department of Agriculture, Animal and Plant Health Inspection Service. Following the detection of Mikrocytos mackini from the February sampled group, additional Kumamoto and Pacific oyster brood and seed stock were sampled from March to May 2011 by producer collections from Humboldt Bay ( $\mathrm{n}=600$, Table 1). Except as noted in Table 1, brood stock was held on long lines and seed stock was held in floating upweller systems (FLUPSY). In addition to results of testing on samples collected in 2011, we also report results from samples collected by an accredited veterinarian for disease surveillance in $2012(\mathrm{n}=600$, see Table 1$)$.

\section{Histological testing}

All oysters were processed for histological examination using routine methods. A transverse section of oysters was made in the dorsal region through the digestive gland, gills and connective tissue, including the labial palps in some cases. This was placed in a histological cassette and fixed in seawater formalin $(10 \% \mathrm{v} / \mathrm{v})$. Histological preparations were processed routinely for paraffin embedment and sections were stained with hematoxylin and eosin. In addition to the examination of tissue for hemocytosis and infectious agents, the height of the epithelium of the digestive gland tubules was rated on a basis of 1 to 4 (low to high), with ratings of 3 and 4 considered to be in the normal active feeding range and ratings of 1 or 2 indicating low height of digestive gland epithelium resulting from limited food availability and starvation.

\section{Molecular testing}

Oysters for PCR analysis were opened in sets of 4 (brood stock) or 6 (juvenile stock) and each set of tissue was preserved separately in non-denatured $95 \%$ ethanol. For brood stock oysters, tissue samples for determination of Mikrocytos mackini infection by PCR consisted of routine collection of ca. $2 \mathrm{~mm}^{3}$ sections of labial palp. Samples from oysters showing no clinical signs of infection were collected in pools of 4 oysters each; for those showing gross signs of dis-

Table 1. Prevalence of Mikrocytos mackini infection in Crassostrea spp. oysters examined from Humboldt Bay, CA, USA, in 2011 and 2012

\begin{tabular}{|c|c|c|c|c|c|c|c|}
\hline Species & Sample location & Life stage & $\begin{array}{l}\text { Sample } \\
\text { date }\end{array}$ & $\begin{array}{l}\text { Analysis } \\
\text { method }\end{array}$ & $\begin{array}{l}\text { Number } \\
\text { examined } \\
\text { (pool size) }\end{array}$ & $\begin{array}{l}\text { Number } \\
\text { positive }\end{array}$ & $\begin{array}{c}\text { Prevalence } \\
\text { estimate } \\
(\%)\end{array}$ \\
\hline C. sikamea & Bird Island, South & Brood stock 2008 & 21 Feb 2011 & Histology & 150 & 30 & 20.0 \\
\hline C. sikamea & Bird Island, South & Brood stock 2008 & 21 Feb 2011 & PCR & $150(4)$ & 13 pools & $11.6^{\mathrm{a}}$ \\
\hline C. sikamea & Mad River Slough & Brood stock 2009 & 26 Mar 2012 & PCR & $150(4)$ & 0 & \\
\hline C. sikamea & East Bay & Brood stock 2008 & 29 Mar 2011 & PCR & $150(4)$ & 24 pools & $27.3^{\mathrm{a}}$ \\
\hline C. sikamea & Bird Island & Brood stock 2009 & 29 Mar 2011 & PCR & $150(4)$ & 2 pools & $1.5^{\mathrm{a}}$ \\
\hline C. sikamea & Mad River & Brood stock 2008 & 11 Apr 2011 & PCR & $150(4)$ & 24 pools & $27.3^{\mathrm{a}}$ \\
\hline C. sikamea & Arcata Channel & Brood stock 2009 & 11 Apr 2011 & PCR & $150(4)$ & 1 pool & $0.8^{\mathrm{a}}$ \\
\hline C. sikamea & Fairhaven nursery & Juvenile stock 2010 & 21 Feb 2011 & PCR & $150(6)$ & 0 & \\
\hline C. sikamea & Fairhaven nursery & Juvenile stock 2011 & 26 Mar 2012 & PCR & $150(6)$ & 0 & \\
\hline C. sikamea & Mad River Slough & Juvenile stock 2011 & 13 Jun 2011 & PCR & $150(6)$ & 0 & \\
\hline C. gigas & Bird Island, South & Brood stock 2008 & 21 Feb 2011 & PCR & $150(4)$ & 0 & \\
\hline C. gigas & Sand Island & Brood stock 2009 & 26 Mar 2012 & PCR & $150(4)$ & 0 & \\
\hline C. gigas & Fairhaven nursery & Juvenile stock 2010 & 21 Feb 2011 & PCR & $150(6)$ & 0 & \\
\hline C. gigas & Fairhaven nursery & Juvenile stock 2010 & 26 Mar 2012 & PCR & $150(6)$ & 0 & \\
\hline C. gigas & Mad River Slough & Juvenile stock 2011 & 17 May 2011 & PCR & $150(6)$ & 0 & \\
\hline
\end{tabular}


ease, lesions were excised and preserved separately. PCR amplification of 546 bp of 18S-rDNA used primers MIKROCYTOS-F and MIKROCYTOS-R, which were designed by Carnegie et al. (2003) to be specific for M. mackini (but see next paragraph). PCR reaction mixtures of $15 \mu \mathrm{l}$ included 5 PRIME HotMaster Taq Buffer at $1 \times$ concentration (with weakly chelated 'self-adjusting' $\mathrm{MgCl}_{2}$ at $2.5 \mathrm{mM}$ ), dNTPs at $0.2 \mathrm{mM}$, primers at $0.2 \mu \mathrm{M}, 5$ PRIME HotMaster Taq DNA

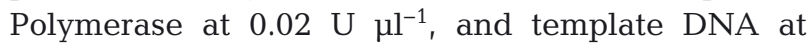
$3.5 \mathrm{ng} \mathrm{pl}^{-1}$. Template DNA consisted of genomic DNA from either the M. mackini-infected or -uninfected Crassostrea sikamea or C. gigas, or a no-template water control. The temperature cycling profile was an initial denaturation at $94^{\circ} \mathrm{C}$ for $2 \mathrm{~min}$; 40 cycles of $94^{\circ} \mathrm{C}$ for $1 \mathrm{~min}, 60.5^{\circ} \mathrm{C}$ for $1 \mathrm{~min}$, and $70^{\circ} \mathrm{C}$ for $1 \mathrm{~min}$; and a final extension at $70^{\circ} \mathrm{C}$ for 10 min. Products were electrophoresed on a $1.0 \%$ agarose gel containing $1 \times$ concentration of Sybr ${ }^{\circledR}$ Safe.

Upon generating positive results for Mikrocytos mackini using the PCR test just described (see 'Results'), we sequenced the complete ITS1-5.8SITS2 rDNA region for confirmatory purposes, as the PCR test is known to also amplify another Mikrocytos sp. from multiple geographic regions (Gagné et al. 2008, Wang et al. 2010, Abbott et al. 2011). PCR primers Mm18S_1435F and pro28S-R were used to amplify and sequence a ca. $700 \mathrm{bp}$ product following methods in Abbott et al. (2011). This sequence is known to be invariant within $M$. mackini but is substantially divergent from the only other Mikrocytos species that has been sequenced at this region (Mikrocytos sp.-BC; Abbott et al. 2011). Sequence data were viewed, edited, and compared against the published M. mackini sequence (GenBank HM563060) using Sequencher v4.8 (Gene Codes).

\section{Prevalence estimates}

Statistical tools are available for estimating prevalence from pooled sample analyses (Cowling et al. 1999), and such estimates assume a fixed pool size and exact knowledge of the sensitivity and specificity of the test methods. These methods were developed due to the use of pooled samples to provide economy when testing large numbers of individuals and are available on an interactive online pooled prevalence calculator (Sergeant 2009). Exact sensitivity and specificity is not known for the PCR method we used for Mikrocytos mackini. Therefore, we made estimates in order to obtain an approximation of prevalence from the pooled values and also varied the sensitivity and confidence levels in the statistical analysis. Using the pooled prevalence calculator, we evaluated the pooled data using the starting assumptions of 0.90 for sensitivity and 1.0 for specificity, with upper and lower confidence limits set at 0.025 and 0.975 . We set the number of pools at 37 because there were 37 full pools of 4 ind. and one half-sized pool of 2 ind. for the 150 pooled oysters.

\section{Humboldt Bay sea surface temperature}

We made an evaluation of Humboldt Bay winter sea surface temperature over a $7 \mathrm{yr}$ period ending in 2011 using data obtained online from NOAA buoy 46212 (NOAA 2011) located near South Spit, Humboldt Bay. To obtain an annual winter average temperature, we averaged all hourly or half-hourly temperature readings, as available, for each reported winter season from October 1 through March 31.

\section{RESULTS}

The first diagnosis of Mikrocytos mackini infection in Crassostrea sikamea was made by histology during the routine annual screening of brood stock oysters for a variety of disease conditions. Initial rapid screening examination revealed foci of infected cells surrounded by a hemocytic reaction (Fig. 1) in 11 of 150 Kumamoto oyster brood stock sampled in February 2011 (Table 1). Subsequent, more detailed histological examination revealed a total of 30 clearly positive individuals. These infected connective tissue foci contained typical microcells identical by histological comparison with previously known M. mackini infection in Pacific oysters (Figs. 2 \& 3). Following the preliminary histological diagnosis, we proceeded to test 3 of the PCR pools corresponding to the histologically positive animals, all of which returned strongly positive results. Subsequently, DNA sequence of the complete ITS1-5.8S-ITS2 region from these sample pools further confirmed the presence of M. mackini: the sequence was $100 \%$ homologous with the published M. mackini sequence, which is known to be invariable within the species based on sequences from over 70 samples collected throughout British Columbia and Washington State (Abbott et al. 2011). We later tested all PCR pools from the initial positive group in order to estimate prevalence. From the additional subsequent 2011 brood stock samples, we found 4 other groups of Kumamoto oyster brood stock from Humboldt Bay positive for 


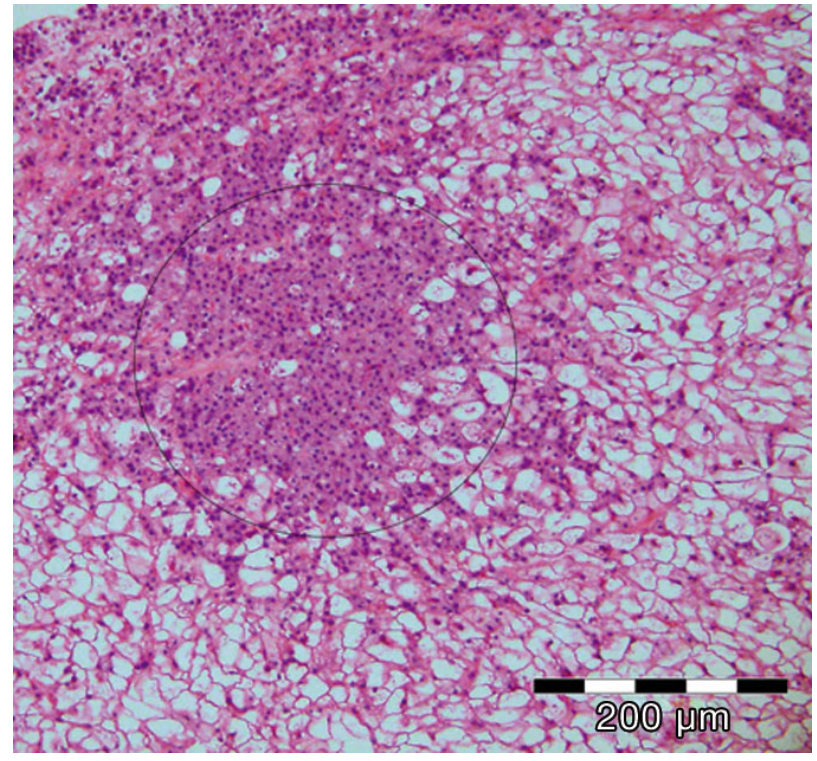

Fig. 1. Crassostrea sikamea. Area of vesicular connective tissue of Kumamoto oyster showing intense hemocytosis reaction to Mikrocytos mackini infection (area outlined by circle)

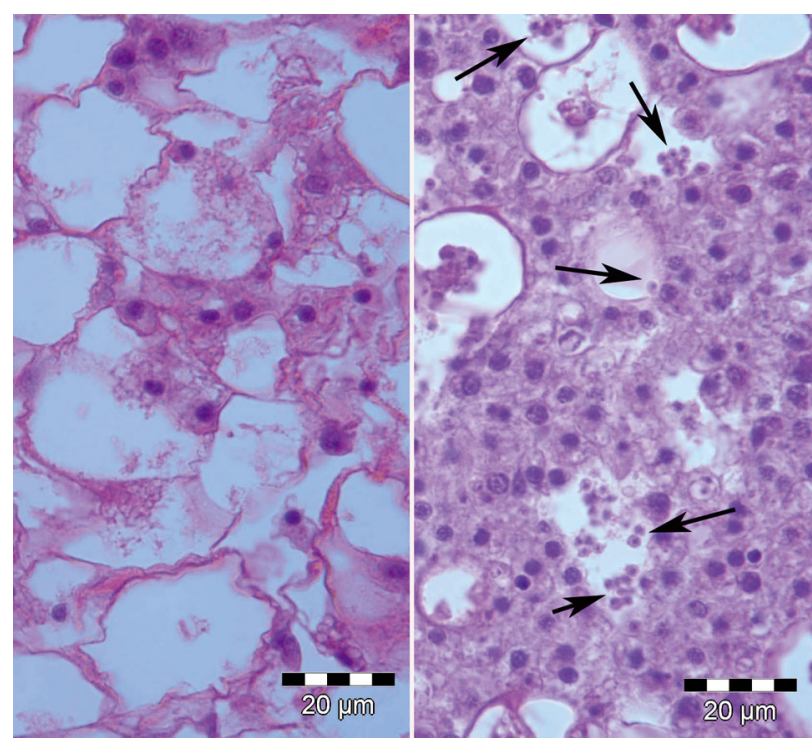

Fig. 2. Crassostrea sikamea. Comparison of uninfected vesicular connective tissue of Kumamoto oysters (left panel) with Mikrocytos mackini-infected tissue (right panel), with examples of the infectious microorganism indicated by the arrows

M. mackini using PCR (Table 1). The 2 tested brood stock groups originating from 2008 seed had a relatively high proportion of positive PCR pools $(24 / 38$ each) compared with 2 brood stock groups originating from 2009 seed (1/38 and 2/38 positive pools). All juvenile Kumamoto oysters and all Pacific oyster brood and juvenile stock from Humboldt Bay tested

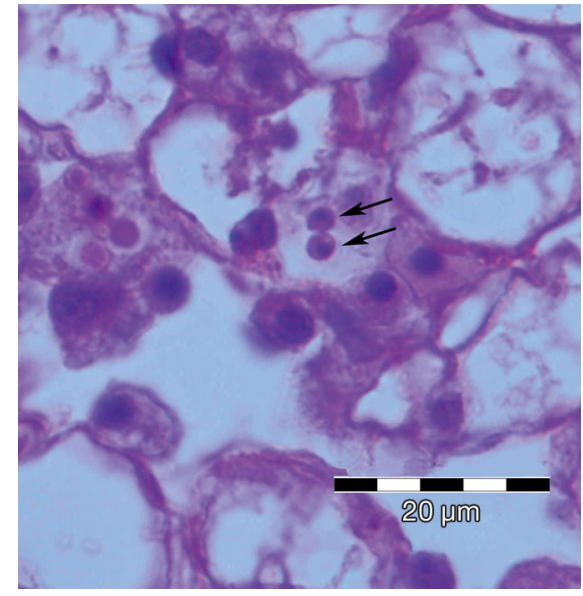

Fig. 3. Crassostrea sikamea. Mikrocytos mackini cells in vesicular connective tissue of Kumamoto oysters (examples indicated by arrows, with additional microcells to the left of those designated by arrows)

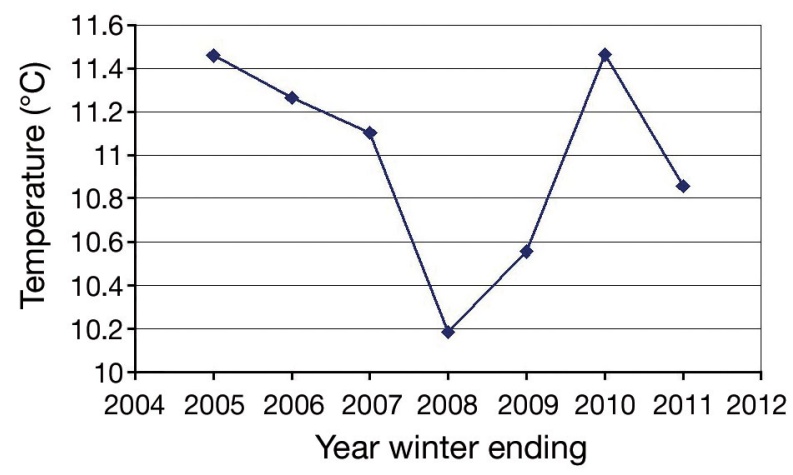

Fig. 4. Surface seawater temperature from October 1 through March 31. The year indicates the March date for each successive data series. Data are from the National Oceanic and Atmospheric Administration, US Department of Commerce buoy located near South Spit, Humboldt Bay. Hourly or half-hourly data, as available, were averaged for each time period indicated

negative for M. mackini in 2011 using the PCR method, as did all brood stock and seed stock samples from both species tested collected in 2012 (Table 1).

The digestive gland condition of the 21 February 2011 sample of Kumamoto brood stock was generally poor, with $61 \%$ of all individuals rated 1 or 2 . The ratings for Mikrocytos mackini-infected oysters (by histology) had $63 \%$ rated as 1 or 2 while the uninfected oysters had $60 \%$ of individuals rated as 1 or 2 . Thus, there was no difference between infected and noninfected individuals. Two of 150 oysters from this group had focal bacterial abscesses, typical of nocardiosis. Humboldt Bay winter sea surface temperature data (Fig. 4) showed average temperatures in 2008 
and 2009 known to be sufficiently low to exacerbate Mikrocytos mackini infection in Pacific oysters from other locations (Hervio et al. 1996; see 'Discussion')

\section{DISCUSSION}

DID is caused by the protozoan parasite Mikrocytos mackini, first discovered in Pacific oysters Crassostrea gigas in British Columbia in the 1960s. The disease can cause visible pustules on the skin surface in Pacific oysters in colder water areas. However, the prevalence of such lesions in Pacific oyster growing areas further south, in Washington State, for example, is generally less than $5 \%$ and the disease is considered to be of incidental health consequence to cultured oysters. Mikrocytos mackini was delisted by the World Animal Health Organization (OIE) as an internationally reportable disease in 2007. Prior to this study, its known geographic range in North America was restricted to British Columbia, Canada, adjacent areas in Washington State, USA (Bower et al. 2005), and one area in Oregon, USA (Farley et al. 1988). Whether it is truly endemic only to this region or whether it may have been introduced to this region with Pacific oysters is not known (Abbott et al. 2011). In the currently reported case, the discovery of DID in Kumamoto oysters was made during routine surveillance and testing, not as a result of morbidity and mortality reports. Thus, we do not know the numerical value for morbidity and mortality that may be attributed to DID in Kumamoto oysters.

This is the first report of Mikrocytos mackini infection in Kumamoto oysters Crassostrea sikamea and the first report of M. mackini in any species of oyster in California. We found the infection first by histology in brood stock oysters from Humboldt Bay in February 2011. By histology, prevalence was $20 \%$ in the first population examined. Upon using PCR to evaluate pooled samples from additional source groups of Kumamoto brood stock oysters from various locations in Humboldt Bay, the prevalence was estimated to range from $\sim 0.8 \%$ up to $\sim 27 \%$ in 2011 (see discussion below of prevalence estimates from pooled samples). Identity of the 2011 positive samples with west coast M. mackini was further confirmed by internal transcribed spacer (ITS) sequence comparison. Evaluation of brood and seed stock Pacific and seed stock Kumamoto oysters from Humboldt Bay by PCR revealed no additional positive samples in 2011 and no brood or seed stock were positive in 2012. However, Humboldt Bay is a relative large body of water and the 2012 negative sam- ples are not interpreted to claim that the bay is free of M. mackini following the 2011 detection. The lack of infection of the known host Pacific oysters is interesting and somewhat unexpected, considering the relatively high prevalence in Kumamoto oysters.

Estimation of prevalence from pooled PCR samples is based on knowledge of certain statistical characteristics of the PCR test (Cowling et al. 1999, Sergeant 2009). To estimate prevalence of Mikrocytos mackini, we made clearly stated assumptions regarding the undetermined specificity and sensitivity of the PCR test. Our prevalence numbers are thus estimates but our purpose is to suggest that there may be a need for a more definitive determination of the comparative sensitivity of PCR and histology. We found an apparently greater relative sensitivity of histology compared to PCR in our study, compared to the Carnegie et al. (2003) study, although we acknowledge that the Carnegie et al. (2003) study utilized a higher sample number for comparison. In the case which initiated this study, for which we have both histology and PCR samples, the prevalence by histology was $20.0 \%$ while the estimated prevalence by PCR was $11.6 \%$ using assumptions of 0.90 PCR sensitivity and perfect specificity (i.e. 1.0). In order to return a prevalence by PCR $(19.7 \%)$ approximating that derived by histology, we had to reduce the assumed sensitivity of the PCR test to 0.60. In all cases of estimated PCR prevalence shown in Table 1, we used assumptions of sensitivity of 0.90 and specificity of 1.0. Reducing the confidence interval to 0.05 and 0.95 made no difference in prevalence outcome. Carnegie et al. (2003) reported that the PCR test had 3 to 4 times greater sensitivity for M. mackini detection than did histology. While our results suggest that the differential sensitivity of histology and PCR might not be as great as that reported by Carnegie et al. (2003), in all cases, a more substantial and systematic comparison should be undertaken. In their study, sample prevalence was lower. If lower prevalence was linked to lower intensity, this might account for lower detection sensitivity using histology. While it initially seems that PCR should be more sensitive, the method utilizes a very small tissue sample and could lose sensitivity when the distribution of the parasite in the tissue is particularly patchy, such as in early or resolving infections. In the population examined by histology and PCR, the estimated prevalence by PCR $(11.6 \%)$ is closer to the histology initial rapid screening examination prevalence $(7.3 \%)$ than the more detailed histological examination result $(20 \%)$, suggesting that PCR may give false negative results when few organisms are present. However, our pri- 
mary point is that it is important to develop a more rigorously defined sensitivity relationship between the 2 methods.

The higher prevalence of Mikrocytos mackini infection in the two 2008 seed origin brood groups, compared to the 2009 seed origin brood groups, is consistent with the longer residence time of the 2008 seed origin oysters in Humboldt Bay. In addition, the outbreak in general, as well as the higher 2008 seed origin prevalence, could have been exacerbated by the drop in surface seawater temperature in Humboldt Bay in 2008 and 2009. Although the 2008 seed origin brood stock was not placed in the bay until after the 2008 winter, the density of infective organisms already in infected hosts in the bay could have increased as a result of low 2008 winter temperatures, thus providing a higher risk of infection. Subsequently, infection of the 2008 seed could have been further enhanced by the still relatively cooler 2009 winter, consistent with the known propensity of this pathogen to infect Pacific oysters more aggressively as seawater temperatures decrease to around $10^{\circ} \mathrm{C}$ (Hervio et al. 1996, Bower et al. 1997).

In addition, the fact that we found significant infections in Kumamoto oysters but no infections in the known susceptible and closely related Pacific oysters in Humboldt Bay suggests that Kumamoto oysters may be more susceptible to infection by Mikrocytos mackini than Pacific oysters. A low digestive gland condition of the Kumamoto oysters sampled in winter from the west coast of North America is a typical finding, as was shown in the evaluation of the initial positive sample from this report. This indicator of poor feed availability, which leads to poor body condition, along with occasional bacterial abscesses, further suggests that the oysters may be more susceptible to any infection during winter, and particularly to infection by $M$. mackini, which requires cold winter temperatures for infection and replication (Hervio et al. 1996).

As a result of the February 2011 finding of Mikrocytos mackini, the California Department of Fish and Game undertook certain legislatively mandated proscriptive actions because of the lack of prior knowledge of this oyster pathogen in California. These actions included an immediate holding action on movement of Kumamoto oyster stocks. After consideration of the emerging data, the following actions were imposed in May 2011. Transfer of Kumamoto oyster stock greater than $20 \mathrm{~mm}$ shell height to other bays in California was prohibited, but transfer of Kumamoto oysters less than $20 \mathrm{~mm}$ was permitted if a PCR test performed 2 to $4 \mathrm{wk}$ prior to the transfer was negative. These requirements will remain in effect until testing is negative for the presence of M. mackini in adult Kumamoto oysters for 2 consecutive years.

In addition, growers using Kumamoto oyster brood stock from the infected areas voluntarily established procedures to more frequently test for presence of the disease agent, optimize brood stock holding conditions, screen and hold potential brood stock in an isolation facility prior to spawning and continue testing seed oyster stock for DID freedom. Using these procedures, all tested hatchery-produced Kumamoto seed stock in 2011 and 2012, derived from Humboldt Bay brood stock, was PCR test negative for Mikrocytos mackini.

Acknowledgements. We thank participating shellfish farms for assistance in providing samples for analysis and Dr. Richard Peterson of the California Department of Food and Agriculture for collection of some samples. We thank Kathy Cooper for necropsy of oysters, Karen Humphrey for conducting the PCR tests, and Gary Meyer and Geoff Lowe from the Pacific Biological Station for their assistance in the laboratory.

\section{LITERATURE CITED}

Abbott CL, Gilmore SR, Lowe GL, Meyer G, Bower S (2011) Sequence homogeneity of internal transcribed spacer rDNA in Mikrocytos mackini and detection of Mikrocytos sp. in a new location. Dis Aquat Org 93:243-250

$>$ Bower SM, Hervio D, Meyer GR (1997) Infectivity of Mikrocytos mackini, the causative agent of Denman Island disease in Pacific oysters Crassostrea gigas, to various species of oysters. Dis Aquat Org 29:111-116

Bower SM, Bate K, Meyer GR (2005) Susceptibility of juvenile Crassostrea gigas and resistance of Panope abrupta to Mikrocytos mackini. J Invertebr Pathol 88:95-99

> Carnegie RB, Meyer GR, Blackbourn J, Cochennec-Laureau N, Berthe FCJ, Bower SM (2003) Molecular detection of the oyster parasite Mikrocytos mackini, and a preliminary phylogenetic analysis. Dis Aquat Org 54:219-227

Cowling DW, Gardner IA, Johnson WO (1999) Comparison of methods for estimation of individual-level prevalence based on pooled samples. Prev Vet Med 39:211-225

Farley CA, Wolf PH, Elston RA (1988) A long-term study of 'microcell' disease in oysters with description of a new genus, Mikrocytos (g. n.), and 2 new species, Mikrocytos mackini (sp. n.) and Mikrocytos roughleyi (sp. n.). Fish Bull 86:581-593

Gagné N, Cochennec N, Stephenson M, McGladdery S, Meyer GR, Bower SM (2008) First report of a Mikrocytoslike parasite in European oysters Ostrea edulis from Canada after transport and quarantine in France. Dis Aquat Org 80:27-35

Hervio D, Bower SM, Meyer GR (1996) Detection, isolation, and experimental transmission of Mikrocytos mackini, a microcell parasite of Pacific oysters Crassostrea gigas (Thunberg). J Invertebr Pathol 67:72-79 
NOAA (National Oceanographic and Atmospheric Administration) (2011) Station 46212, South Spit, Humboldt Bay, California. National Data Buoy Center, Stennis Space Center, MS. Available at www.ndbc.noaa.gov/station page.php? station $=46212$

PCSGA (Pacific Coast Shellfish Growers Association) (2010) Shellfish High Health Program Guideline. Available at www.pcsga.org/pub/uploads/Shellfish_High_Health_ Framework_Plan_Jan_2010.pdf

Quayle DB (1961) Denman Island oyster disease and mortality, 1960. Manuscript Report 713. Fisheries Research Board of Canada, Ottawa

Quayle DB (1982) Denman Island oyster disease 1960-1980.

Editorial responsibility: David Bruno,

Aberdeen, UK
BC Shellfish Mariculture Newsl 2:1-5

Quayle DB (1988) Pacific oyster culture in British Columbia. Department of Fisheries and Oceans Canada, Ottawa

Sergeant ESG (2009) EpiTools epidemiological calculators. AusVet Animal Health Services and Australian Biosecurity Cooperative Research Centre for Emerging Infectious Disease. Available at http://epitools.ausvet. com.au

Wang ZW, Liang YB, Lu X (2010) Use of histopathology, PCR and in situ hybridization methods to detect the parasite Mikrocytos sp. in Pacific oyster Crassostrea gigas from the northern coast of the Yellow Sea, China. Aquat Living Resour 23:125-130

Submitted: June 22, 2012; Accepted: August 16, 2012 Proofs received from author(s): November 14, 2012 